\title{
A Detailed Study on the Importance of Microfinance on the Banks in Uzbekistan
}

\author{
Nagimov Fakhriddin, Zhang Ping \\ School of Management and Economics, \\ Zhejiang University of Science and Technology, Hangzhou, CN.
}

\begin{abstract}
This research work investigated the Importance of Microfinance on the Banks in Uzbekistan. The study examined how micro-finance activities and features such as group membership, pre-loan training, cross guarantee ship, loan size, technical and managerial training, among others, impact on the survival, growth, productivity and performance of Micro finance in Uzbekistan. The hypotheses formulated were developed around the theories of financial growth model, pecking order theory, and contract theory. Four hypotheses were raised and tested at 0.05 significant levels. The findings revealed that micro finance and micro-financing enhance survival of Micro finance but not sufficient for growth and expansion of such Micro finance. The result also revealed that microfinance has positive effects on productivity and performance of local entrepreneurs. The findings from the interview sessions revealed that micro financing is not effective and substantially being practiced in Uzbekistan as many grant more individual loans than group based loans, thereby increasing their running cost and putting their portfolio at risk. We also recommend that enterprises supported by MFBs should be linked up with larger financing window like the fund or Strategic Partners for expansion and growth funding after survival.
\end{abstract}

DOI: $10.7176 /$ RJFA/12-20-02

Publication date:October $31^{\text {st }} 2021$

\subsection{Background}

Since Uzbekistan attained independence in 1991, considerable efforts have been directed towards industrial development. The initial efforts were government-led through the vehicle of large industry, but lately, emphasis has shifted to Small and Medium Scale Enterprises (SMEs) following the lessons learnt from the success of SMEs in the economic growth of Asian countries (Ojo, 2003). Since 1986, government had reduced its role as the major driving force of the economy through the process of economic liberalization entrenched in the IMF pill of Structural Adjustment Programme. Emphasis, therefore, has shifted from large-scale industries to small and medium- scale industries, which have the potentials for developing domestic linkages for rapid and sustainable industrial development. Attention was focused on the organized private sector to spearhead subsequent industrialization programmes. The incentives given to encourage increased participation in these sectors were directed at solving and/or alleviating the problems encountered by industrialists in the country, thereby giving them opportunity to increase their contribution to the Gross Domestic Product (GDP). The micro, Finance represent about 87 per cent of all firms operating in Uzbekistan (USAID, 2005). Non-farm micro, small and medium enterprises account for over 25 per cent of total employment and 20 percent of the GDP (SMEDAN, 2007) compared to the cases of countries like Indonesia, Thailand and India where Micro, Finance contribute almost 40 percent of the GDP. However, as argued by Ojo (2003), all these SME assistance programmes have failed to promote the development of SMEs. This was echoed by Yumkella (2003) who observes that all these programmes could not achieve their expected goals due largely to abuses, poor project evaluation and monitoring as well as moral hazards involved in using public funds for the purpose of promoting private sector enterprises. Among the reasons given were that the small-sized enterprises are quite vulnerable to economic failure arising from problems related to business and managerial skills, access to finance and macroeconomic policy. Despite MSME's important contributions to economic growth, small enterprises are plagued by many problems including stagnation and failure in most sub-Saharan African countries (Bekele, 2008). In Uzbekistan, the problem is not limited to lack of long-term financing and inadequate management skills and entrepreneurial capacity alone, but also, includes the combined effect of low market access, poor information flow, discriminatory legislation, poor access to land, weak linkage among different segments of the operations in the sector, weak operating capacities in terms of skills, knowledge and attitudes, as well as lack of infrastructure and an unfavourable economic climate.

Lack of access to finance has been identified as one of the major constraints to small business growth (Carpenter, 2001; Anyawu, 2003; Lawson, 2007). Despite all these efforts, the contribution of SMEs in the industrial sector to the Nation's GDP was estimated to be $37 \%$ compared to other countries like India, Japan and Sri Lanka and Thailand where SMEs contributed $40 \%, 52 \% 55 \%$ and $47.5 \%$ respectively to the GDP in 2003, (UNCTAD, 2003), hence the need for alternative funding window. In 2005, the Federal Government of Uzbekistan adopted microfinance as the main financing window for micro, small and medium enterprises in 
Uzbekistan. The Microfinance Policy Regulatory and Supervisory Framework (MPRSF) was launched in 2005. The policy, among other things, addresses the problem of lack of access to credit by small business operators who do not have access to regular bank credits. It is on this platform that we intend to examine the impact of microfinance on small business growth, survival, as well as business performance of MSEs operators.

Majority of the micro finance (MSEs) in Uzbekistan are still at a low level of development, especially in terms of number of jobs, wealth and value creation. This is because $65 \%$ of the active population, who are majorly entrepreneurs, remain unserved by the formal financial institutions. The microfinance institutions available in the country prior to 2005 were not able to adequately address the gap in terms of credit, savings and other financial services. As reported by the $\mathrm{CBN}$, the share of micro credit as a percentage of total credit was $0.9 \%$, while its contribution to GDP was a mere 0.2 This initiated an important turning point in the microfinance industry with the establishment of the Microfinance Bank (MFB) as an institutional vehicle for privately owned, deposit taking Microfinance Institutions (MFIs). Five years down the line, though microfinance has proven to be one of the ways of bridging the resource gap created in the Uzbekistan economy, there are still some undesirable problems experienced against its proper execution. The lack of documentation of the practice of micro financing in Uzbekistan has made it difficult to formulate supportive programmes for the growth of the sector.

\subsection{Motivation for the Study}

The aim of this study is to estimate the effects of micro financing on business performance of MSEs in Uzbekistan. The primary objectives are to:

1. Assess the contributions of micro financing to the survival of MSEs in Uzbekistan.

2. Analyze the effects of micro financing on MSE growth and expansion capacity in Uzbekistan.

3. Ascertain the effects of microfinance on the productivity of MSEs operators in Uzbekistan.

4. Examine the effects of non-financial services of microfinance institutions on MSEs Business performance in Uzbekistan.

This study therefore becomes significant in filling this observed gap by testing empirically the impact of both the financial and non-financial services offered by Microfinance Banks on small business growth/survival and by examining the capability of Microfinance institutions in enhancing the expansion capacity of small businesses in Uzbekistan. The study also contributes to the literature on microfinance and small business survival.

Successive governments in Uzbekistan have always had a policy programme for SMEs, but most of the programmes have failed to achieve sustainable growth in the SMEs sub-sector. Most of the government assisted-programmes have themselves become failures. The findings of this study is expected to inform policy makers regarding the direction of further research into interventionist programmes for MSEs in Uzbekistan. The study is also of great importance to Microfinance Institutions, in the sense that it is expected to assist the microfinance institutions in assessing the effectiveness of their programmes and to know which variables contribute most to small business growth and survival.

\subsection{LITERATURE REVIEW}

2.2 Empirical Literature Review

\subsubsection{Concepts of Micro, Small and Medium Enterprises and Microfinance}

A review of the literature on Micro Finance shows that the definition significantly varies from country to country depending on factors such as the country's state of economic development, the strength of the industrial and business sectors, the size of MSMEs and the particular problems experienced by MSMEs (Harabi, 2003). Hence, there is no uniform or universally accepted definition of MSMEs (Investment Climate Assessment (ICA), 2009). In Uzbekistan, parameters such as asset base (excluding land), the number of workers employed and the annual turnover are used for the classification of MSMEs. Carpenter (2001) maintains that there is no one definition for SMEs; they are defined in Uzbekistan and other countries based on one or all of the following: the size or amount invested in assets excluding real estate; the annual turnover and the number of employees.

\subsection{Concepts in Microfinance}

Microfinance is the provision of financial services adapted to the needs of low income people such as microentrepreneurs, especially the provision of small loans, acceptance of small savings deposits, and simple payments services needed by micro-entrepreneurs and other poor people (USAID, 2000). It is the provision of financial services to the economically active poor who are hitherto un-served by the mainstream financial service provider. Microcredit is commonly defined in terms of loan amount as a percentage of average per capita income. In the context of Uzbekistan, with a per capita GDP of (about \$300) in 2003, loans up to (about/approximately \$350) would be regarded as micro loans, while micro savings are defined as savings accounts with a balance of less than N8,400 (about \$50), that is less than $20 \%$ of the average annual income per capita (USAID, 2004). The Central Bank of Uzbekistan $(\mathrm{CBN}, 2005)$ defines microfinance as the provision of financial services to the 
economically active poor and low income households. These services include credit, savings, micro-leasing, micro-insurance and payment transfer, to enable them to engage in income generating activities. The Microfinance Policy defines the framework for the delivery of these financial services on sustainable basis to the Micro, Small and Medium Enterprises (MSMEs) through privately-owned Microfinance Banks. In another contribution, Ojo (2007) defined microfinance as small scale financial services that are provided to rural/informal small scale operators for farming, fishing, trading, and building of houses and to engage in any other productive and distributive activities. Mosley (2001) defined microfinance as financial services for poor and low-income clients. In practice, the term is often used more narrowly to refer to loans and other services from providers that identify themselves as "microfinance institutions" (MFIs). " Corroborating this position, Yunus (2003) opines that microcredit is based on the premise that the poor have skills which remain unutilized or underutilized and that it is not the lack of skills that makes poor people poor. . Charity is not the answer to poverty. Poor people have proved time and again that they are able to repay these loans in time (United Nations, 2005). Yunus (2003) also observes that these loans are character-based rather than collateral-based. Consultative Group to Assist the Poor (CGAP) reiterated that, microfinance allows poor people to protect, diversify, and increase their sources of income.

\subsection{Impact Assessment of Microfinance}

Garmaise and Natiridada (2010) provide direct evidence on the impact of asymmetric information on both financing and operating activities through a study of credit evaluations of microfinance institutions (MFIs). They employ a regression discontinuity model that exploits the eligibility criteria of an evaluation subsidy offered by a non-profit consortium. The evaluations dramatically cut the cost of financing and found the effect strongest for commercial lenders and for short-term MFI-lender relationships. The impact of evaluations on the supply of finance is mixed. Evaluated MFIs lend more efficiently, extending more loans per employee. Kotir and Obeg Odoom (2009), in a study of 139 households in one rural area of the Upper West Region of Uzbekistan, found that, (a) Beneficiaries of micro-credit divert a significant portion of such loans into household consumption albeit with moderate impact on household productivity and welfare and (b) Micro-credit has modest impact on rural community development. Matovu (2006), using pooled data from Uganda, concludes that all the women clients reported increase in their incomes which has improved their standard of living, enabled them to send their children to school; pay their medical bills, feed their families, and cope with future crises using their savings; the women have been empowered economically. Khandker (2005) observes microfinance supports mainly informal activities that often have a low return and low market demand. It may therefore be hypothesized that the aggregate poverty impact of microfinance is modest or even nonexistent.

\subsection{Theoretical Review}

\subsubsection{Financial Growth Theory}

The growth cycle model predicts that as firm grows, it will gain access to venture capital (VC) as a source of intermediate equity and mid-term loans as a source of intermediate debt. At the final stage of the growth paradigm, as the firm becomes older, more experienced and more informational transparent, it will likely gain access to public equity (PE) or long-term debt. Problems related to financing are dominant in the literature with regard to small firms. There are numerous empirical studies describing inadequate financing as the primary cause of MSMEs' Owualah, 2007). The capital structure of smalls firm differs significantly from larger firms because small firms rely more on informal financial market which limits the type of financing they can receive. The small firm's initial use of internal financing creates a unique situation in which capital structure decisions are made based on limited financing options. Researchers have found that certain attributes of small firms influence the type of funds available to finance the firm's operations ( Hall et al., 2000, Romano et al.,2001;). Model adapted from Berger and Udell (1998), Angel financing is a type of microfinance where an individual or a corporate organization raises limited amount of capital for a micro entrepreneur at start up or for expansion with less stringent conditions for repayment. The expected rate of return on investment is usually very low but high enough to offset risk.

Table 2.3: Financial Growth Cycle

\begin{tabular}{|l|l|l|}
$\begin{array}{l}\text { Very small firms, possibly with no } \\
\text { collateral and no track record. } \\
\downarrow\end{array}$ & $\begin{array}{l}\text { Medium -Sized Firms. Some track records. } \\
\text { Collateral available, if necessary. }\end{array}$ & $\begin{array}{l}\text { Large firms of known } \\
\text { risk and track record. } \\
\downarrow\end{array}$ \\
\hline Initial Insider Financing & Venture Capital & Public Equity \\
\hline$\downarrow$ & $\downarrow$ & \multicolumn{1}{l}{} \\
\hline Angel & Medium - term financial Institutions. & $\begin{array}{l}\text { Long term financial } \\
\text { institutions. }\end{array}$ \\
\hline
\end{tabular}

2.4.2 Pecking Order Theory

It sheds light on the incentives that drive SMEs capital structure decisions. This theory proposes that firms prefer 
to use internal sources of capital first and will resort to external sources only if internal sources are inadequate. This theory has been found to be relevant to the financing of SMEs. Most SMEs start with internal financing before looking for external sources. Older firms, by definition, have had more opportunities to accumulate retained earnings than younger companies and thus more funds are available to finance operational growth. Pecking order theory suggests that those funds should be used before external capital sources are tapped. It has been noted that small businesses' differ in their capital structure but their intense reliance on pecking order is only one of the variables that make small businesses financing decision unique. Small businesses' rely on private capital markets, while larger firms are financed through public market. Information on small businesses is much less readily available than information on larger firms which can be picked up in the annual reports. In most cases, the cost of capital for small businesses is usually higher than it is for larger firms. When loaning to small businesses, most financial institutions require the owners of the small businesses to personally guarantee the loan. This is supported by Hall et al. (2000) who found that firm's size is positively related to long-term debt and negatively related to short-term debt. In further support. Thus, smaller firms are more likely to rely on internal funds. Romano et al. (2001) found a significant relationship between the size of the firm and the use of debt.

\subsection{Small Business Development (Stages of Small Business Development)}

The success stage is characterized by two possibilities: disengagement or growth. At the disengagement stage, the company is healthy, but ceases to grow. The professional staff comes on board. This can be the last development stage and may last long. The other possibility is to strive towards growth: at the success-growth stage, the entrepreneur marshals resources for growth. It becomes important to train managers to meet the need of the growing business. Once it has successfully passed through this stage, the company proceeds to the takeoff stage, and the main focus then is on how to grow rapidly and how to finance that growth. The main concern at this stage borders on delegation, transferring responsibility and controls from the entrepreneur to others in order to improve managerial effectiveness. At the resource-maturity stage, the management is decentralized and the organization is adequately staffed. Systems are extensive and well developed. After this stage, two clear possibilities emerge: continued performance or suffocation.

\subsection{MSMEs and Economic Development in Uzbekistan}

Even if there are controversies on definitions, what is not contestable is the contribution that MSMEs are making to the Uzbekistan economy. A cursory glance at the structure of MSMEs in Uzbekistan reveals that 50\% are engaged in distributive trade, $10 \%$ in manufacturing, $30 \%$ in agriculture and the remaining $10 \%$ in other services. About $10 \%$ of the total manufacturing output and $70 \%$ of industrial employment are MSMES. MSMES also promote industrial and economic development through the utilization of local resources, production of intermediate goods and the transfer/transformation of rural technology. In fact MSMEs are generally regarded as the engine driving the growth of this and other economies and provide the best opportunity for job creation, redistributing income and rural development (SMEDAN, 2007). In Uzbekistan, the Small and Medium Scale Enterprises (SMEs) constitute an important backbone of the Uzbekistan economy. Economically, this sector holds the key to sustainable development of the country. This group is dominated by wholesale and retail trade which accounts for about $49 \%$ of employment; manufacturing accounts for (30\%). Other numerically significant sectors include repair of vehicles $(3.2 \%)$, transport $(2.9 \%)$, hotels and restaurants $(2.6 \%)$ and building and construction (1.8\%). Manufacturing is dominated by food processing (18.7\%), textiles, clothing and leather goods $(3.8 \%)$, wood and wood furniture $(3.3 \%)$ and metals \& metal products $(1.1 \%)$. Non-farm micro, small and medium enterprises account for over 25 per cent of total employment and 20 percent of GDP. By global standards, large enterprises are very few in Uzbekistan. They account for a disproportionately large share of the GDP. Because their links with the rest of the economy are weak, their impact on economic growth has been limited and often distorted (SME National Policy, 2007). The importance of micro and small enterprises (MSEs) to the socio-economic development of low and middle-income economies is well documented (Daniels, 2003; UNIDO, 2003; ILO, 2002;). Thus, there is a great deal of interest in the performance of firms in the microenterprise sector and its scope is to generate employment, both through new business start-ups and the expansion of existing businesses. Most microenterprises are characterized by low productive capacity which is manifested in low rates of growth and high mortality rate (ILO, 2002; UNIDO, 2003).

\subsection{Microcredit and Microenterprise}

Fasoranti, Akinrinola and Ajibefun (2006) examined the impact of microcredit and training on the efficiency of small scale entrepreneurs in Uzbekistan. The study is premised on determining the link between access to credit, training and technical efficiency and highlighting other significant factors that influence the level of efficiency in the baking, furniture making, and burn brick making micro-enterprises.

Ogunrinola and Alege (2008), found the operation of UNDP- sponsored MFI to be beneficial to micro businesses in the rural based areas of Uzbekistan. Forty-two (42) of the enterprises that received microcredit 
reported business success as a result of the application of the loan received. Micro-entrepreneurs in the study achieved a very high loan repayment rate of 96 per cent and reduced rate of business failure and also restricted rural-urban migration.

The result showed that, one, individual liability compared to group liability leads to no change in repayment but is better at attracting new clients and keeping existing ones. Two, there is a statistically significant evidence of some of the mechanisms discussed in the group liability literature, such as screening and monitoring, but they did not find that it adds up in an economically meaningful way to higher (or lower) default.

Hartarska and Nadolnyak (2008) used the financing constraints approach to study the impact of microfinance on access to credit for microenterprises in Bosnia and Herzegovina. Using sensitivity analysis and multiple regression analysis, the data and method employed produced results consistent with more traditional impact studies on Bosnia for the same period.

\subsection{Theoretical Findings}

The review of literature covered in this study has led to the following findings:

1. Regular participation in microfinance enhances small business survival. Bekele and Zeleke (2008) found ability to convert profit into investment, good managerial ability, entrepreneur's level of education, ability to make profit and regular participation in microfinance to be major determinants of small business survival.

2. Access to external credit increases the growth of both employment and sales. Brown, Earle and Lup (2004) found strong evidence that access to external credit increases the growth of both employment and sales. They also found taxes to constrain growth. Olutunla and Obamuyi (2008), provide evidence that external credit enhances growth, but emphasize that the right amount of loan at the right time is crucial. Managers must be hired with a focus on the company's future rather than on maintaining its current condition and status quo. Fasoranti et al. (2006) also find easy credit access to be a major determinant in efficiency of the small scale entrepreneur.

3. Lack of access to finance has been identified as one of the major constraints to small business growth (Anyanwu, 2003; 2009; Lawson, 2007).

4. Well-structured entrepreneurship training programmes facilitate the efficiency and productivity of entrepreneurs. (Fasoranti et al. 2006). Competitive pressure enhances productivity growth (Harding et al; 2004)

\subsection{METHODOLOGY}

\subsection{Research Design}

The multiple-method strategy was adopted for this study so as to reduce the possibility of personal bias by not depending on only one method or response from only one firm or sector. Adopting this approach enhances the authenticity of the study. The study was designed to combine primary survey-based data with secondary information from bank records. Both qualitative and quantitative data were used in a variety of ways, including a detailed overview of survey results in terms of a general profile and a model of Uzbekistann micro and small firms. A well-structured questionnaire was administered to operators and semi - structured interviews were conducted with Senior Bank Officials to document the practice and process of micro financing in Uzbekistan. The idea behind this was to obtain cross-referencing data and some independent confirmation of data, as well as a range of opinions. The panel data, that is the combination of primary and secondary longitudinal data already gathered by the banks gives a better perspective of the clients/customers' profile over a period of time and makes better judgment possible. Panel data facilitate a precise specification of timing so that the effect of a factor is measured after the factor has changed. What is also important is that they permit the use of fixed firm specific effects. This is suitable for the present study because we are looking at a variable in retrospect (microfinance) and relating it to the enterprise (survival, performance, and growth). The interview sessions contained questions directed to senior officials of the bank in mostly face-to-face interview to document the process, practice and mode of operations of micro financing in Uzbekistan.

\subsection{Model and Method of Data Analysis}

The data generated for the study were analyzed using both descriptive and inferential analytical techniques. The analytical techniques employed are basically two: Survival Analysis and multiple regression analysis using the ordinary least square (OLS) approach. The survival analysis incorporated Cox Regression Analysis and Kaplan Meier Survival Analysis technique. The adequacy of the fitted model was assessed using the likelihood ratio test. Analyses were done using SPSS statistical package version 15.1. The duration of survival was measured for each of the MSEs in the study using the past five years' records and financing method as treatment control. The model employed in Kauffman and Wang (2003) and Bekele and Zeleke (2008) were adapted, while a Survival Analysis technique was used to determine the factors responsible for survival of MFB-financed MSEs in Uzbekistan. The 
data comprises of secondary data obtained from the banks records and primary data obtained from field survey of 623 MSEs in South West Uzbekistan. The period covered for the study is 2004 to 2008. Eight explanatory variables were used, drawn from the four categories of factors affecting small business survival identified in literature. The variables were analyzed to know their level of influence, strength and significance on small business survival. Survival analysis (SA) technique was chosen as the main analytical technique for this study because:

\subsection{Methods for Empirical Analysis}

Since the aim of this aspect of the study is to see the impact of microfinance on survival and viability of MSEs in Uzbekistan, analysis was done using two methods: First, we performed a semi-parametric survival analysis using a proportional hazards model. And two, we used nonparametric techniques to estimate the survival estimate for the businesses and compare the results with those of the semi-parametric analysis.

In the analysis of firm survival, we can observe the failure time of a firm, or its continued existence. Thus, a firm in our sample will still be at risk at time $t$ if its survival time or the censored time is greater than or equal to $t$.

The Cox model assumes the following functional form for the hazard function:

$\log h_{0}(t)=\alpha+\beta_{1} x_{i 1}+\beta_{2} x_{i 2}+\ldots+\beta_{K} x_{i k}$

In Equation 2, $h 0(t)$ is the unknown baseline hazard function and $\beta$ is a vector of parameters to be estimated. This expression enables us to capture the baseline hazard rate as a result of the method of financing via $h 0(t)$, and the impact of other factors that vary across firms through their vector of time-varying covariates, $X$, via the estimated parameters, $\beta$.

Based on this hazard function, the corresponding survival function is given as:

$S(t, x, b)=\left[S_{o}(t)\right]^{\exp (\mathrm{x} \beta)}$

In Equation 3, $S O(t) \in\{0,1\}$ is the baseline survival function. This expression represents the likelihood that a firm will continue to be in existence at time $t$, in view of the baseline rate of survival among observed firms and other economic variables, firm and financing method characteristics that also vary over time will be examined, given that it has been in operation continuously in prior periods.

For a firm $i$ that is still at risk at time $t i$, its likelihood of failure at time $t i$ compared to other firms that are at risk at time $t i$ is given as

$$
L_{i}(\beta)=\frac{h\left(t_{i}, x_{i}, \beta\right)}{\sum_{j \in R\left(t_{i}\right)} h\left(t_{i}, x_{j}, \beta\right)}=\frac{e^{x_{i} \beta}}{\sum_{j \in R\left(t_{i}\right)} e^{x_{j} \beta}}
$$

In equation $4, \mathrm{R}\left(t_{i}\right)$ is set of all firms that are still at risk at time $t_{i}$. For a data set that contains $n$ firms, the partial likelihood is given by

$$
L_{p}(\beta)=\prod_{i=1}^{n}\left[\frac{e^{x_{i} \beta}}{\sum_{j \in R\left(t_{i}\right)} e^{x_{i} \beta}}\right]^{c_{i}}
$$

In Equation 5, $\mathrm{ci}$ is 1 if the observation is not censored and 0 if the observation is censored. Using this partial likelihood function, the parameters can be estimated without specifying the baseline hazard function.

Non-Parametric Analysis. In addition to the Cox regression, a Kaplan-Meier model was used to perform a

descriptive analysis. The Kaplan-Meier estimator is defined as:

$$
\hat{S}(t)=\prod_{t_{i} \leq t} \frac{n_{i}-d_{i}}{n_{i}}
$$

where $n_{i}$ is the number of firms that are still at risk at time $t i$ and $d i$ is the number of firms that actually failed at time $t i$. The Kaplan-Meier estimator provides a reading on the likelihood of survival at time $t$ based on the survival history of all firms. Using results from the semi-parametric analysis, we stratify the data set into different subgroups such as microenterprise and small enterprise and different sectors of the economy covered in the study and calculate the Kaplan-Meier estimator for each group. We then use standard statistical tests to compare the differences among the groups and compare the results with our regression results from the proportional hazards models.

\subsection{Multiple Regression Analysis}

The evaluation of the relationship between dependent and independent variables was performed using the multiple regression technique. The first step consisted of defining the variables of interest. In this study, small business growth proxies by annual sales growth rate over the five years is the dependent variable (SBG) and key predictors of MSEs' expansion and growth are the independent variables. The independent variables are divided 
into three different categories consisting of owners' characteristic variables, firm characteristics variables and microfinance variables. The owners' characteristic variables consist of variables such as, owners' age, owners' level of education, owners' marital status and gender. The firm characteristic variables consist of business age, form of business, business size, business location, and business registration, while the microfinance characteristics variables consist of size of technology/asset/equipment loan received, technology related training received, asset loan duration, Asset Loan repayment and loan utilization. The variables are: $E A g e_{1}, E E_{2}, M S_{3}$, $E_{4}$, Bizage, Bizform $_{6}$, Bizsize $_{7}$, Bizloc $_{8}$, Bizreg $_{9}, A L S_{10}, A L D_{11}, A L R_{12}, L U_{13}, T T_{14}$. In this case, small business growth was regressed on the set of explanatory variables that predicted MSEs growth as it relates to microfinance. The coefficient of the variables measures the marginal effects of the independent variables on small business growth measured by annual sales growth in this aspect of the study.

The general form for the model in the work is given as:

$S B G=f\left(X_{1} \ldots X_{n}\right)$

Where,

$S B G=$ dependent variable is a measure of small business growth;

$f=$ a function to be specified

$X=a$ vector of explanatory variables of microfinance characteristics that pertain to business growth

In specific form, equation 6 translates into equation 7 thus:

$S B G=a+b_{1} X_{1}+b_{2} X_{2}+b_{3} X_{3}+\ldots \ldots \ldots,+b_{n} X_{n}+e$

Where,

$S B G=$ dependent variable (small business growth)

$a=$ constant

$\mathrm{x}_{1}, \mathrm{x}_{2}, \mathrm{x}_{3}, \ldots, \ldots, \ldots, \ldots, \mathrm{x}_{\mathrm{n}}$ are independent variables (Entrepreneurs' age, Entrepreneurs' level of education, Marital Status, Gender, Business age, Form of business, Business size, Business location, business registration, size of asset loan received, duration of asset loan, repayment of asset loan, loan utilization, technology related training received by the entrepreneur).

$b_{1}, b_{2}, b_{3}, \ldots, \ldots, \ldots, \ldots$, bn are regression coefficients which determine the contribution of the independent variables

$\mathrm{e}=$ residual or stochastic term (which reveals the strength of $b_{1} x_{1} \ldots b_{n} x_{n}$; if $e$ is low, this implies that the amount of unexplained factors is low, then the residual $\mathrm{R}$ and $\mathrm{R}^{2}$ will be high and vice versa.

\subsection{DATA PRESENTATION, ANALYSIS AND INTERPRETATION \\ 4.1 Multiple Regression Analysis}

A major problem that users of our MFB 'sample' could encounter would be if firms are giving loans based on their expected growth in subsequent years. Although we have been concerned about this possibility, there are several reasons why it seems unlikely that the possibility would produce bias in our data. First, as in the case of many MFBs, the loan agencies evaluate loan applications based on the credit history and particularly the previous cash flow of the applicant, and they do not even request a business plan for the future. In nearly all cases, no collateral is required but a satisfactory guarantor. Second, the segregation of equation to isolate certain variables as peculiar to a particular segment gives a more realistic view of different position and thirdly, we include other variables to control for differences in demand conditions for microfinance. Among these variables are firm level characteristic variables such as business age, business size, business location, registration status, and type of business activities. The presence of MFBs in the state where the enterprise operate can influence their access to micro loan and other credit as may be available. Other facts, such as managerial assistance, technical assistance, and regular contact with Loan Officers go a long way to affect the growth and business performance of an enterprise. A firm operating in a place like Uzbekistan is more likely to get all the experts help as may be require for business growth. Another type of selection bias could result from the fact that our database includes more surviving firms; but worthy of mention is the fact that some firms may be inactive, particularly as seen in the data; there are firms that do not get the loan continuously for two years. It should be noted that factors that increase growth also tend to raise the probability of survival of an enterprise. This suggests that our estimates of the effects will be understated, if not put in proper perspective, an obvious caveat about our results if not properly stated.

\subsection{Analysis and Discussion}

\subsubsection{Effects of Microfinance on Small Business Growth by Category of Business}

Table 4.1 below present's results from the regression of the average sales growth rates on different variables characterizing the firms and micro financing.

On impact of owner characteristics variables on the expansion capacity of MSEs, the result obtained shows that entrepreneur's age has a positive relation with the expansion capacity of the firm but it is not statistically significant for the three samples. The result obtained for owner's education shows positive relationship between 
different level of education and expansion capacity of the MSE, but of all the different level of education tested, only OND/NCE and university education for small firm are statistically significant. The result shows that for a unit increase in OND/NCE education level of MSE entrepreneurs, sales will growth by $0.30 \%, 0.18 \%$, and $0.24 \%$ for the total sample, small firms and micro firms respectively; the result obtained for total sample is statistically significant at 5\% while result obtained for small firms and micro firm's samples are statistically significant at $10 \%$. The result also shows a significant relationship between university education and small firm growth. The result shows that a unit increase in university education will increase sales growth of small firm entrepreneurs by $1.8 \%$ and it is statistically significant at $10 \%$. The result obtained can be relied upon for inference and it has correct sign as expected in small business theory. Cressy (2006), Salim (2005), More educated/skilled entrepreneurs may have better start-up conditions, for example in the form of capital saved from earlier employment (Makasure et al. 2008)

Table 4.1Multiple Regression Analysis of Effects of Microfinance on Small Business Growth by Category of Business

\begin{tabular}{|c|c|c|c|c|c|c|}
\hline \multirow{2}{*}{ Constant } & \multicolumn{2}{|c|}{$\begin{array}{l}\text { Column I } \\
\text { Total Sample } \\
\text { Coefficient } \\
\text { t- statistics }\end{array}$} & \multicolumn{2}{|c|}{$\begin{array}{l}\text { Column II } \\
\text { Small Firms } \\
\text { Coefficient } \\
\text { t-statistics } \\
\end{array}$} & \multicolumn{2}{|c|}{$\begin{array}{l}\text { Column III } \\
\text { Micro Firms } \\
\text { Coefficient } \\
\text { t- statistics }\end{array}$} \\
\hline & $15.320 *$ & 8.561 & $9.001 *$ & 6.581 & $16.631 *$ & 5.588 \\
\hline \multicolumn{7}{|l|}{ Owners Characteristics } \\
\hline Owner's age & 0.858 & 1.002 & 0.786 & 1.134 & 1.231 & 0.982 \\
\hline Education-No formal & 0.061 & 0.812 & 1.051 & 0.101 & 0.056 & 1.114 \\
\hline Primary education & 0.012 & 0.544 & 0.102 & 0.845 & 0.196 & 1.329 \\
\hline Secondary Education & 0.719 & 0.433 & 2.111 & 1.432 & 1.010 & 1.490 \\
\hline OND/NCE education & $0.306 * *$ & 2.561 & $0.180 * * *$ & 3.062 & $0.242 * * *$ & 1.852 \\
\hline B.Sc Education & 0.132 & 1.444 & $1.822 * * *$ & 1.501 & 1.011 & 1.227 \\
\hline M.Sc/PhD Education & 0.001 & 1.127 & 1.161 & 0.120 & 0.012 & 1.135 \\
\hline Marital Status-Single & 0.081 & 0.114 & 0.031 & 0.561 & 0.008 & 0.916 \\
\hline Marital Status-Married & 1.452 & 0.871 & 0.239 & 0.222 & 1.011 & 1.016 \\
\hline Separated/Divorced & 0.345 & 1.418 & 0.124 & 0.671 & 1.017 & 1.010 \\
\hline \multicolumn{7}{|l|}{ Firm Characteristics } \\
\hline Firm age & $-0.014 * * *$ & -1.612 & $-0.075 * *$ & -2.515 & $-1.924 * * *$ & -1.823 \\
\hline $\begin{array}{l}\text { Business formation - sole } \\
\text { proprietorship }\end{array}$ & 0.210 & 1.121 & 0.524 & 1.002 & 0.552 & 1.014 \\
\hline Partnership & 0.222 & 0.188 & 0.341 & 1.099 & 1.013 & 0.681 \\
\hline Family business & 0.018 & 1.488 & 0.231 & 1.013 & 0.090 & 0.518 \\
\hline Firm Size & $0.111 * *$ & 3.713 & $-0.022 *$ & -5.912 & $0.381 * *$ & 2.645 \\
\hline Bus. location- urban area & $0.053 *$ & 5.569 & $0.089 *$ & 4.225 & $0.018 * *$ & 2.164 \\
\hline Bus. location- rural area & 0.189 & 0.102 & 1.120 & 1.019 & 0.008 & 0.771 \\
\hline Business registration & $0.027 *$ & 3.158 & $0.052 * *$ & 2.041 & 0.045 & 1.003 \\
\hline \multicolumn{7}{|l|}{$\begin{array}{l}\text { Microfinance } \\
\text { characteristics }\end{array}$} \\
\hline Size of asset loan & 0.034 & 1.393 & 0.167 & 0.811 & $0.014 * *$ & 2.598 \\
\hline Duration of asset loan & 4.403 & 0.187 & 1.508 & 1.448 & $0.108^{*}$ & 1.872 \\
\hline Repayment of asset loan & -0.079 & -1.128 & -1.911 & -0.721 & $-0.693 *$ & -4.814 \\
\hline Loan Utilization & 0.048 & 1.212 & 0.846 & 1.131 & $0.041^{*}$ & 5.116 \\
\hline Technology training received & $0.029 * *$ & 3.586 & $1.057^{*}$ & 6.681 & $0.114 * *$ & 2.123 \\
\hline $\mathrm{R}-$ squared & 0.321 & & 0.352 & & 0.271 & \\
\hline Adjusted R-Squared & 0.281 & & 0.311 & & 0.211 & \\
\hline No. of Observation & 502 & & 135 & & 367 & \\
\hline F-test statistics & $0.362(0.41$ & 117) & $0.385(0.5$ & & $1.237(0.3$ & \\
\hline
\end{tabular}

The effect analysis of microfinance on Micro and small Enterprises (MSEs) expansion. The dependent variable is sales growth over a five-year period between 2004 and 2008. Column 1 presents the result of the total sample, column II and column III split the data into firms with ten or more employees and less than ten employees respectively. Note $*=1 \%$ level of significance $* *=5 \%$ level of significance $* * *=10 \%$ level of significance

The result obtained on firm characteristics variables shows that business age has an inverse relationship with small business growth and expansion capacity proxy by average sales growth. The general pattern between 
firm age and growth seems to be that young firms are more likely to grow faster. The result shows that a unit increase in firm age will decrease sales growth by $0.01 \%$ for the total sample and $0.07 \%$ and $1.9 \%$ for small firms and micro firms respectively, and they are all statistically significant at $10 \%$ for the total sample and micro firms respectively and at 5\% for small firms' sample. On technology related training received by the entrepreneurs, the result obtained shows that technology-related training received by entrepreneurs significantly affects sales growth, thereby enhancing the expansion capacity of MSEs. Specifically, the result shows that a unit increase in technology-related training received by the entrepreneur will cause annual sales growth to increase by $0.029 \%$ for the total sample and by $1.0 \%$ and $0.1 \%$ for small firms and micro firms respectively. They are all statistically significant at $5 \%$ and $1 \%$ respectively. Previous studies provide strong evidence of a positive association between the use of technology and business performance, with observed differences in profit level across enterprises and sectors reflecting varying innovative environments (Bigsten et al., 2003; Chapelle \& Plane, 2005; Daniels, 2003).

The coefficient of determination that is the $\mathrm{R}^{2}$ for the three columns is $0.32,0.35$ and 0.27 for the total sample, small firms and micro firms respectively and the adjusted $\mathrm{R}^{2}$ of $0.28,0.31$ and 0.21 shows the level of variation in the dependent that is explained by the independent variables in the three samples. The $\mathrm{R}^{2}$ obtained in this study is acceptable for panel data like we have in this study.

The decision rule is that we reject the null hypothesis, if the calculated F-value is greater that the critical Fvalue. In this case, the calculated f-value is 0.362 while the critical f-value is 1.94 , so we accept our null hypothesis. Besides, the calculated f-value is not statistically significant. Hence we can conclude that microfinancing as practiced by Micro Finance Banks in South-West Uzbekistan does not enhance MSEs' growth. But variables such as Entrepreneur's education, firm age, firm size, firm location and firm registration enhance sales growth, while other factors like size of asset loan, duration of asset loan and frequency of repayment of loan do not enhance sales growth.

\subsubsection{Multiple Regression Analysis of Effect of Microfinance on Small Business Operators Productivity by Category.}

The Table below presents results from the regression of micro-financing variables on Entrepreneur's productivity. The result in column I of the Table represents the total sample. In columns II and III we split the sample into small and micro firms. Column II presents observations for small firms (i.e. firms with more than 10 employees) and column III presents observations for micro firms (i.e. firms with less than 10 employees). The constant, which is also the intercept, reveals that when all the variables are zero, the Entrepreneur's productivity will be 37.7 for the total sample and 17.9 and 8.6 for small and micro firms respectively. The result obtained is significant at $1 \%$. The coefficient for entrepreneur's age is negative and significant at $1 \%$ for the total sample and $5 \%$ for small firms and micro firms. This is expected: as the entrepreneur advances in age, he becomes less productive. The coefficient for different level of education shows positive correlation but not all is statistically significant. The result shows that when OND/NCE level of education increase by one level, entrepreneur's productivity increases by 0.3 unit for small firms and it is statistically significant at $5 \%$. The result also shows that as Entrepreneur's university education increases by one unit, his productivity will increase by 7.7 units for the total sample and by 6.2 and 8.6 unit for small and micro firms respectively. The result obtained is significant at $1 \%$ for the total sample and at $5 \%$ for small firms and micro firms samples. This implies that B.Sc level of education has positive correlation with productivity; the significance of education hinges on the fact that it enhances the stock of human knowledge and management skills which consequently enhance productivity. This confirms the findings of Fasoroti et al., (2006) that the entrepreneur's level of education enhances productivity. On hours worked per day, the result shows that if the number of hours worked per day is increased by an hour, the entrepreneur's productivity will decrease by 0.09 unit for the total sample and by 0.04 and 0.3 unit for small and micro firms respectively. This implies that the more hours an entrepreneur spends on his business, the less productive he becomes; 
Table 4.2 Multiple Regression Analysis of Effect of Microfinance on Small Business Operators' Productivity by Category.

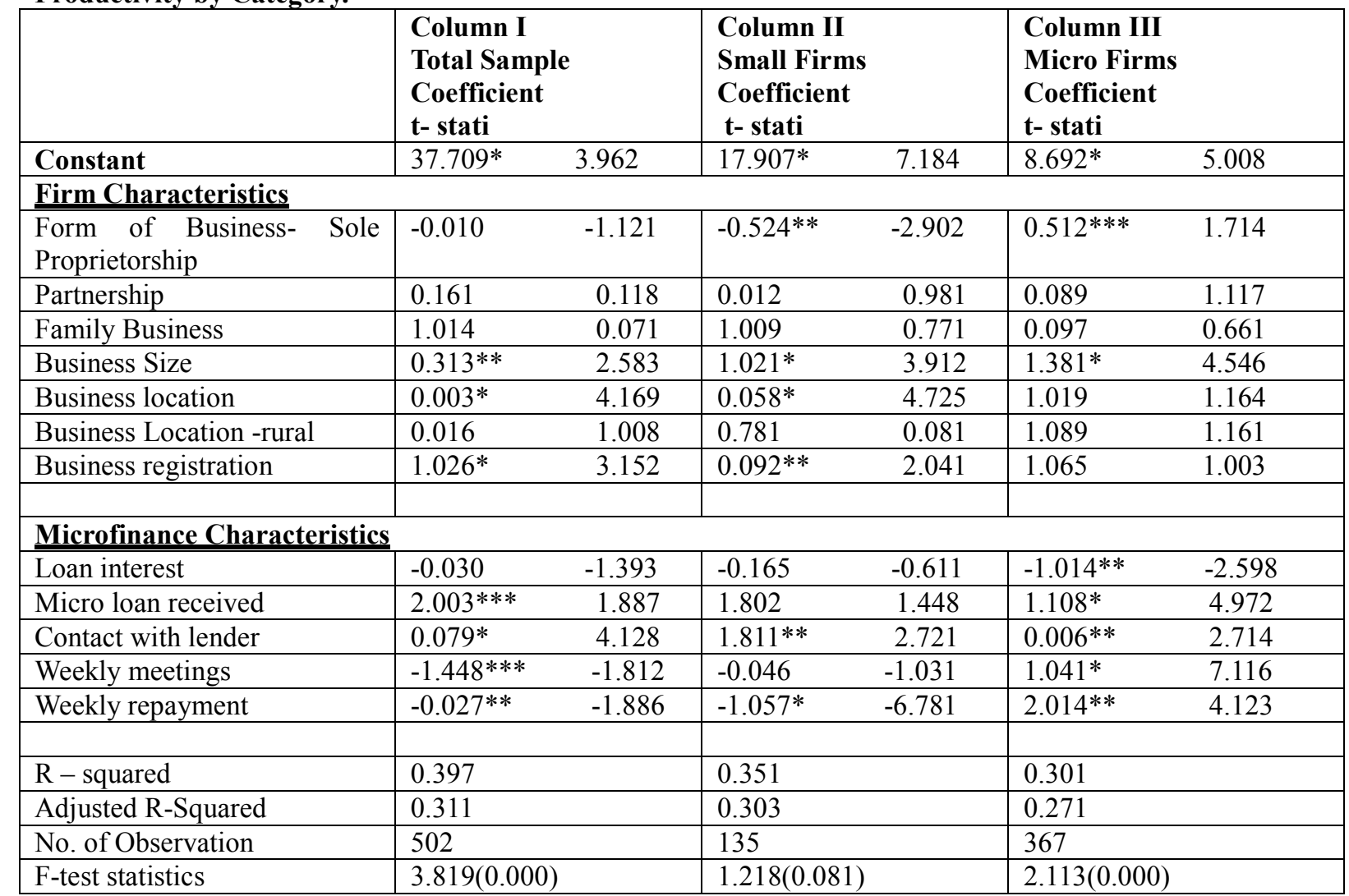

Note $^{*}=1 \%$ level of significance, $* *=5 \%$ level of significance, $* * *=10 \%$ level of significance

The effect analysis of microfinancing on Entrepreneur's productivity. Productivity is measured as output over resource input at time t. The result of the total sample is presented in column I, the data is later split into two, result of firms with equal or more than 10 employees is presented in column II i.e (small firms), while result of firms with less than 10 employees (i.e micro firms) is presented in column III.

Individual entrepreneur therefore needs to find the optimal number of hours that he/she needs to commit to his business for him to be productive. The result is expected and confirms past empirical research (Shiferaw, 2007). The coefficient for business experience which is a proxied by number of years in business is positive and significant at $5 \%$ for the three models. This implies that the longer the years of experience of an entrepreneur, the more productive he is (Shiferaw, 2008; Fasoranti et al., 2006). The magnitude of beta coefficient of entrepreneurial training for all the three models is high, positive and statistically significant at $1 \%$ for the total sample and $5 \%$ for small firm and micro firm samples. This implies that entrepreneurial training significantly enhances small business productivity.

On firm level characteristics, sole proprietorship form of business formation shows a negative and significant impact for small firm sample, and positive and significant impact for micro firm samples. This may be due to the fact that sole proprietorship business formation may not suitable to enhance productivity of small scale entrepreneur, but may be suitable for micro firms. The coefficient for business size shows a positive and significant impact on entrepreneur's productivity. This implies that the larger the firm the more productive the entrepreneur and the chances of survival for the enterprise (Bernard and Jensen, 2007). Business location is positive and significant at $1 \%$ respectively for the total sample and small firm sample, but not significant for micro firms. The coefficient for rural sample is positive but not significant in the three models. The effect of registration of business seems to be size-based. The coefficient for business registration is positive and significant for the total sample and small firms at $1 \%$ and $5 \%$ significance level, but positive and not significant for the micro firm sample. In small firms, registration enhances credibility, opens up access to rationed resources and reduces transaction cost, thus enhancing the growth and productivity of the firm. In micro firms on the other hand, registration may not enhance productivity appreciably. For instance, operating outside the purview of government affords firms more flexibility in input use as local conditions change (Sleuwagen and Goedhuys, 2002).

The result on weekly meetings shows a negative relationship between weekly meetings and entrepreneurs' productivity. The result for the total sample shows that as the weekly activity increases the entrepreneur's 
productivity decreases by 1.44 units for the total sample, and 0.049 and 1.04 unit for small and micro firms respectively. The result obtained is statistically significant for the total sample and micro firms at $1 \%$, but not statistically significant for small firms. Barnes et al (2001) found frequency of meeting to have a negative impact on business performance for repeat and continuing client. Also, result for weekly repayment shows a negative relationship between entrepreneur's productivity and weekly repayment. The result shows that as repayment activities increases, entrepreneur productivity drop by 0.02 for total sample and 1.05 and 2.014 for small and micro firms respectively. The result obtained is statistically significant at $1 \%$ for small firm sample and $5 \%$ for total firm and micro firm samples. This implies that the weekly repayment schedule is too frequent for all entrepreneurs and it affects their productivity negatively.

The coefficient of determination, that is, the adjusted $\mathrm{R}^{2}$ for the three samples are $0.31,0.30$ and 0.27 for the total sample, small firm and micro firms respectively. This is acceptable for a cross-sectional data, like we have for this study. The overall statistic is significant at $1 \%$ for the three columns. The decision rule is that when calculated F-value is significant we reject the null hypothesis and accept the alternative hypothesis. We therefore conclude that, microfinance enhance productivity of micro entrepreneurs and the factors that positively affect entrepreneur's productivity are Entrepreneurs' education, business experience, business registration, contact with lender, and micro loan received while other factors such as weekly meetings, and frequency of loan repayment do not enhance entrepreneur's productivity in South Uzbekistan.

\subsubsection{Multiple Regression Analysis of Effect of Microfinance on Small Business Operators Productivity by Kind of Business}

The result on Entrepreneur's productivity was also split into kind of business activities so as to determine the impact of different variables tested on Entrepreneur's productivity by kind of business. The result obtained is presented in table 4.37 below. The intercept, which is the constant, is positive and statistically significant for all the sectors of the economy except for the service industry, which is negative and statistically significant at $5 \%$. The result obtained for owners' characteristics variables shows inverse relationship between entrepreneurs' age and entrepreneurs' productivity in all industry except for trading industry. This implies that as entrepreneur grows older in trading industry their productivity increase but result obtained is not significant. On entrepreneurs' Level of Entrepreneur's primary education is found to have positive correlation with Entrepreneur's productivity and it is statistically significant for all kind of trade except for artisans which is not significant. Probably level of education do not have significant impact on entrepreneurs' productivity among artisans. The result obtained for hours worked per day shows an inverse relationship between hours worked per day and entrepreneurs' productivity and statistically significant in trading, manufacturing and agriculture subsector but not significant in artisans and service industry. The result on business experience and entrepreneurial training is also positive and significant in all sectors except for artisans and agricultural sectors.

On firm characteristics variables, the coefficient for business age shows positive and significant correlation with entrepreneur's productivity in all sectors, the coefficient for form of business is positive for all sectors but not significant in artisans, agriculture and service subsectors. The coefficient for business size is also positive for all sectors but not significant in agriculture sector while the coefficient for geographical location (urban) is positive and significant in all sectors 
Table 4.3 Multiple Regression Analysis of Effect of Microfinance on Small Business Operators Productivity by Kind of Business

\begin{tabular}{|c|c|c|c|c|c|}
\hline & $\begin{array}{l}\text { Column I } \\
\text { Trading } \\
\text { Coef t-stat }\end{array}$ & $\begin{array}{l}\text { Column II } \\
\text { Artisan } \\
\text { Coef } \\
\text { stat }\end{array}$ & $\begin{array}{l}\text { Column III } \\
\text { Manufacturing } \\
\text { Coef t-stat }\end{array}$ & $\begin{array}{l}\text { Coulmn IV } \\
\text { Agriculture } \\
\text { Coef t-stat }\end{array}$ & $\begin{array}{l}\text { Coulmn V } \\
\text { Service } \\
\text { Coef t-stat }\end{array}$ \\
\hline Constant & $\begin{array}{l}8.471^{*} \\
2.029\end{array}$ & $\begin{array}{l}0.036 \\
3.316\end{array}$ & 10.449 & 16.441 & $\begin{array}{l}-0.013 \\
1.923\end{array}$ \\
\hline \multicolumn{6}{|c|}{ Firm Characteristics } \\
\hline Business age & $\begin{array}{l}0.015^{*} \\
4.602\end{array}$ & $\begin{array}{l}1.430 * * \\
2.822\end{array}$ & $\begin{array}{l}0.313^{* *} \\
3.115\end{array}$ & $\begin{array}{l}0.047 * \\
5.528\end{array}$ & $\begin{array}{l}0.053 * * \\
1.832\end{array}$ \\
\hline Form of Business & $\begin{array}{l}0.010^{* *} \\
1.621\end{array}$ & $\begin{array}{l}0.606 \\
1.302\end{array}$ & $\begin{array}{l}1.003 * * \\
1.758\end{array}$ & $\begin{array}{l}0.052 \\
0.174\end{array}$ & $\begin{array}{l}0.055 \\
0.694\end{array}$ \\
\hline Partnership & $\begin{array}{l}0.221 \\
0.778\end{array}$ & $\begin{array}{l}0.322 \\
0.567\end{array}$ & $\begin{array}{l}1.201 \\
1.047\end{array}$ & $\begin{array}{l}1.321 \\
0.731\end{array}$ & $\begin{array}{l}0.456 \\
0.651\end{array}$ \\
\hline Family business & $\begin{array}{l}1.012 \\
1.048 \\
\end{array}$ & $\begin{array}{l}1.211 \\
0.980 \\
\end{array}$ & $\begin{array}{l}0.344 \\
1.304 \\
\end{array}$ & $\begin{array}{l}1.004 \\
1.115 \\
\end{array}$ & $\begin{array}{l}0.321 \\
0.332 \\
\end{array}$ \\
\hline Business Size & $\begin{array}{l}0.018^{*} \\
4.713\end{array}$ & $\begin{array}{l}0.053 * * \\
2.402\end{array}$ & $\begin{array}{l}4.314^{*} \\
5.778\end{array}$ & $\begin{array}{l}0.238 \\
0.880\end{array}$ & $\begin{array}{l}0.045^{* *} \\
1.873\end{array}$ \\
\hline Bus loc-Urban & $\begin{array}{l}0.615^{*} \\
4.216\end{array}$ & $\begin{array}{l}1.008^{* *} \\
1.915\end{array}$ & $\begin{array}{l}0.023 * * \\
1.622\end{array}$ & $\begin{array}{l}0.321 * * \\
2.976\end{array}$ & $\begin{array}{l}0.183^{*} \\
3.991 \\
\end{array}$ \\
\hline Bus loc-Rural & $\begin{array}{l}1.201 \\
1.012 \\
\end{array}$ & $\begin{array}{l}0.355 \\
1.413 \\
\end{array}$ & $\begin{array}{l}0.311 \\
1.204 \\
\end{array}$ & $\begin{array}{l}0.034 \\
1.241 \\
\end{array}$ & $\begin{array}{l}0.542 \\
1.033 \\
\end{array}$ \\
\hline \multicolumn{6}{|c|}{ Microfinance Characteristics } \\
\hline Loan interest & $\begin{array}{l}-5.755^{*} \\
5.093\end{array}$ & $\begin{array}{l}-0.009 \\
1.411\end{array}$ & $\begin{array}{l}-0.017 \\
1.015\end{array}$ & $\begin{array}{l}-0.41 * * \\
1.961\end{array}$ & $\begin{array}{l}-3.841^{*} \\
4.186\end{array}$ \\
\hline $\begin{array}{ll}\text { Micro loan } \\
\text { received }\end{array}$ & $\begin{array}{l}2.055^{* *} \\
1.536 \\
\end{array}$ & $\begin{array}{l}0.091 * \\
5.135\end{array}$ & $\begin{array}{l}1.799 \\
0.491 \\
\end{array}$ & $\begin{array}{l}1.303 \\
1.452 \\
\end{array}$ & $\begin{array}{l}1.110 \\
0.135\end{array}$ \\
\hline $\begin{array}{l}\text { Contact with } \\
\text { lender }\end{array}$ & $\begin{array}{l}1.312^{* *} \\
1.928\end{array}$ & $\begin{array}{l}1.610^{*} \\
2.090\end{array}$ & $\begin{array}{l}5.302^{* *} \\
1.913\end{array}$ & $\begin{array}{l}1.293^{*} \\
6.820\end{array}$ & $\begin{array}{l}1.331^{*} \\
5.619\end{array}$ \\
\hline Weekly meetings & $\begin{array}{l}-0.077 * * \\
1.781\end{array}$ & $\begin{array}{l}-1.387 \\
1.331\end{array}$ & $\begin{array}{l}-0.141 * * \\
1.786\end{array}$ & $\begin{array}{l}-3.113 * * \\
1.923\end{array}$ & $\begin{array}{l}-1.051 * * \\
1.881\end{array}$ \\
\hline Weekly repayment & $\begin{array}{l}-0.042^{* *} \\
2.185\end{array}$ & $\begin{array}{l}-1.060 * \\
4.862\end{array}$ & $\begin{array}{l}-5.006^{*} \\
4.515\end{array}$ & $\begin{array}{l}-3.511 * * \\
1.741\end{array}$ & $\begin{array}{l}-1.651 \\
0.329 \\
\end{array}$ \\
\hline $\mathbf{R}-$ squared & 0.381 & 0.290 & 0.201 & 0.285 & 0.222 \\
\hline $\begin{array}{l}\text { Adjusted } \\
\text { Squared }\end{array}$ & 0.315 & 0.221 & 0.187 & 0.230 & 0.196 \\
\hline $\begin{array}{ll}\text { No. } & \text { of } \\
\text { Observation }\end{array}$ & 238 & 86 & 54 & 89 & 33 \\
\hline F-test statistics & $\begin{array}{l}2.183 \\
(0.000)\end{array}$ & $\begin{array}{l}1.132 \\
(0.230)\end{array}$ & $\begin{array}{l}1.318 \\
(0.038)\end{array}$ & $\begin{array}{l}1.972 \\
(0.005)\end{array}$ & $\begin{array}{l}2.961 \\
(0.000)\end{array}$ \\
\hline
\end{tabular}

The effect analysis of microfinance on Entrepreneur's productivity split into nature of business activities. Column I to column V are as detailed below.

Except for the agricultural sector which is not significant. Rural location is not significant for all sectors.

On micro finance characteristics, the result obtained from our regression estimate shows an inverse relationship between loan interest and Entrepreneur's productivity in all sectors but only

Statistically significant in trading, agriculture and service subsectors. The use of micro loan significantly affects Entrepreneurs productivity in the trading and artisans sub-sector, but it is not significant in the manufacturing, agriculture, service subsectors. The coefficient for contact with lenders is positive and statistically significant in all sectors. This implies that positive relationship with lenders enhance entrepreneurs' productivity. The result obtained on weekly meetings shows a negative relationship with entrepreneurs' productivity in the trading, service,

Manufacturing, artisan and agriculture sectors and statistically significant at $5 \%$ in all sectors except for artisans sector where it is not significant. This implies that weekly meetings do not enhance entrepreneur's productivity. The result on weekly repayment of loan received by the entrepreneur also shows a negative relationship for all business type and they are all statistically significant except for service sector. This implies that weekly repayment of loan affect entrepreneurs' productivity negatively. The significance and impact of 
each of these variables on entrepreneurs' productivity vary across the five sub-sectors; therefore it is difficult to draw general and definite conclusions as to the impact of any one factor.

The coefficient of determination, adjusted $\mathrm{R}^{2}$, seems tolerable for all the sectors because of cross sectional data used for this study. But the overall statistics show F-value calculated to be $2.183,1.132,1.318,1.912$, and 2.961 for trading, artisans, manufacturing, agriculture and service industry respectively, only the result obtained for trading, agriculture and service is significant while the result for manufacturing and artisan is not significant. We therefore reject our null hypothesis for the trading, agriculture and service sectors and accept our alternative hypotheses for the three sectors. But for the manufacturing and artisans we accept our null hypothesis, which implies that microfinancing enhances entrepreneurs' productivity in the trading, agriculture and service subsectors but does not enhance productivity of entrepreneurs in the manufacturing, and artisan sub-sector in Uzbekistan

\subsection{The Operations, Process and Practice of Microfinance in Uzbekistan}

An analysis of the total number of licensed Banks showed that there was a high concentration of the banks in Uzbekistan (147), the States accounted for 47.5 per cent of the total number of approved MFBs. The remaining 52.5 per cent of the total number of approved MFBs. The spread reveals that the MFBs are concentrated in States located in the southern geo-political zones and thinly spread in the Northern geopolitical zones as summarized. To join a Micro Finance Bank in Uzbekistan is not strenuous; an individual can walk in or can be introduced by other individual who is already a client/customer to the Bank. Most categories of clients/customers of MFBs are self-employed individuals who own and manage their business outfit. Categories of clients/customers range from agriculture/agro-based micro business entrepreneurs such as poultry farmers, oil palm farmers, grain farmers, legumes and cotton farmers, orchards farmer, fisher men/women, snail farmers to individuals involved in the processing of any of the above product. Also, among the MFB customers are tailors and fashion designers, arts and craft, sculptors, carpenters and furniture makers, motor vehicle repairers, vulcanizes, shoe makers and shoe menders, newspaper vendors, electricians, water packaging and sales men. Included also are general retailers and merchandisers, GSM repairers, small restaurant operators, musical and video rental shop operators, party rentals operators etc. One of the Bank Managers commented that

"Anyone in business can join Microfinance bank in as much as he/she is ready to abide by the rules, but acquisition of a particular skill or interest in a particular sector of the economy is necessary to have a focus".

Response from the MFB interview reveals that most of the MFB do not carry out pre-site research before the banks are situated in a particular location, neither do they target specific group. Most of the banks were sited base on the discretion of the owners. It was also revealed that, for some of the banks, their officials meet with the resident of a community to inform them about the bank project, familiarizing the community members with the objectives, policies and programmes of the banks even before the banks are sited, but most of the banks interviewed do not inform the residents about their intension before setting up the banks in the community. Also, most of the banks do not visit the homes of prospective participants for personal interview and to assess their economic situation so as to enable the banks develop financial product that will be suitable for the community.

To qualify for loan, applicants go through a pre - loan training or business training. A pre - loan training is compulsory and it takes an average of $2-6$ weeks depending on the bank. The pre-loan training covers areas such as records keeping, minute writing and other areas of training, which depend on the training needs of the group in focus. After the training, an exchange visit is made by some banks to successful clientele. This is to expose the new client/customer to other business environment so as to learn new ways and techniques of doing business and also to conceptualize their own business. After successful repayment of the first loan, the client qualifies for the next stage of loan. It takes an average of $3-6$ months after joining the bank before a client/customer can get a loan. The client/customer must have completed the pre-loan training and get a good report from the field officer allocated to him/them before loan can be granted.

Savings were done weekly on group level. Individuals could also save and withdraw any additional amount saved. In most of the banks, $10 \%$ of savings is held against members who have outstanding loans, while an open access to new voluntary saving products exist. The savings account was structured as follows: General Members' savings account, Special savings account, Associate Member's savings account: the amount saved varied among groups and it could be withdrawn any time, long-term savings and short-term deposits. Interest on savings varied among banks but an average savings deposit rate is estimated at 2-3\% which is comparable with that of other banks. The savings rate in the MFBs is therefore not attractive; hence their inability to mobilize lots of savings from the poor.

The Board of Directors of MFBs is primarily responsible for the corporate governance of the banks. To ensure good governance of the banks, the Board of Directors ensures the establishment of strategic objectives, policies and procedures capable of guiding and directing the activities of the banks; the means to attain same, as well as the mechanism for monitoring the Management's performance. The management of the day-to-day affairs of the banks is the responsibility of the Management team; the Board of Directors is, however, 
responsible for monitoring and overseeing Management's actions. Consequently, the licensed microfinance bank operates under a diversified and professional board of directors.

Two categories of clientele exist in Uzbekistan microfinance bank today, individual client and group base client. There are more of individual client than group base client in Uzbekistan MFBs. Individual member client borrow just like in normal banking system mostly with collateral and the interest rate for individual are much higher than that of groups. Some banks do not use collateral but request three guarantors to indemnify in case of default. Most of the banks give group loan especially for first time applicant especially under the regular loan category; it is after the complete repayment of the first loan and the level of exposure of the customer/client expanded that individual loan is granted. Group membership is encouraged to facilitate loan approval; groups are formed along business line, similar age group, similar educational background, and socio economic standing. Group members should be neighbors but not relatives. The groups are formed by group members and they elect group leaders themselves. The groups operate like normal co-operatives bodies, they have Chairperson, Assistance Chairperson, Secretary, Treasurer, Chief Whip and Ex-officials. Most of the group consists of five to ten members. The bank assigned Field Officer to each group. The Field Officer attends the group meetings and assists the group with their training needs and record keeping in preparation for loan. Oral group recognition test are carried out by the Branch Manager to ensure that all members of the group know each other and understand the principles and procedures of the project.

Response from the interview also revealed that each member must submit a simple loan proposal, within the limits of the available loan amount; the loan proposal explains the intended productive use of the funds. One of the managers commented that "the proposal must be approved initially by the group for those operating within the group before going to the bank manager for final approval". Loan disbursement is not staggered among group member (from the weakest member of the group to the strongest member of the group) in most of the banks; once the loan is approved all group members get their share of the loan at the same time in most banks in Uzbekistan. It was also revealed that the loan officers monitor the borrower closely to ensure that loan given are use for the stated purpose and the borrower maintains a good repayment record, "close supervision by the field officers is an ongoing process".

\subsection{Conclusion}

Entrepreneurs in the small and micro sub-sector of the economy in Uzbekistan require access to finance for their businesses to thrive on a sustainable basis. Although, the MSE sector contributes significantly to the national economy, the sector has so far not been given due recognition commensurate with level of the contribution. Although financial issues are important to all firms, results from this study show that both financial and nonfinancial services obtained from MFBs have highly benefited MSEs in Uzbekistan and have facilitated the sharing of business skills and innovative ideas, as well as alleviated the acute shortage of finance to an extent. The policy implication of this study is that, microfinancing contributes significantly to an enhanced entrepreneurial environment by making the business environment more conducive and narrows the resource gap for small businesses. When properly harnessed and supported, microfinance can scale-up beyond the microlevel as a sustainable part of the process of economic empowerment by which the poor improve their situation. Based on findings from this study, the use of MFBs has potentials for enhancing the performance of small businesses in three major ways- regular participation in microfinancing, offering of non - financial services, and as a means to enhance entrepreneur's productivity. If we consider the variation in impact of these factors on the intensity of MSE growth and survival within any one sub-sector, it is possible to define a common series of critical factors for sub-sets of firms. This suggests that policies aimed at promoting the performance of micro and small enterprises should adopt a sectoral approach. Thus, approaches and resources should address the most critical determinants of performance in focal sub-sectors, aiming to augment access to critical resources and, perhaps, overcome the disadvantages that cannot be easily varied.

1. Enterprises supported by MFBs should be linked up with larger financing windows like the SMEEIS fund or Strategic Partners as suggested by Ojo (2003). The linkages should be such that the entrepreneurs would be serviced through their MFBs based on social capital. This will enable MFBs to introduce loan products and strategies targeted at financing technology acquisition by MSEs.

2. In order to encourage technology acquisition for MSE expansion, MFBs can categorize their loans into low and high interest loans. The conventional loans to clients can be maintained as high interest loans, while loans for capital assets or technology acquisition should be low interest loans, which can be secured by a mortgage over the fixed asset so acquired by the micro-borrower. To achieve this, the Microfinance Banks can be recapitalized.

3. MFBs should increase the duration of their clients' asset loans, or spread the repayment over a longer period of time, or increase the moratorium. This will enable the clients to have greater use of the loan over a longer period for the acquisition of capital assets and technology.

4. The MFBs should employ collective group-based loan disbursement and staggered disbursement strategy; this 
will reduce the default rate and the volume of portfolio at risk.

5. The microfinance banks should reduce the gap between their savings deposit rate and the lending rate by mobilizing more savings from the informal financial market which is an integral part of their operating environment.

\section{REFERENCES}

Anyanwu, C. M. (2003). The Role of Central Bank of Uzbekistan in Enterprises Financing, Paper delivered at Small and Medium Industries Equity Investment Scheme (SMIEIS) Seminar. CBN Training Centre, Lagos.

Barnes, C., and Keogh, E. (2001). An Assessment of the Impact of Zambuko's Microenterprise Program in Zimbabwe: Baseline Findings. Assessing the Impact of Microenterprises (AIMS) Paper, Washington, D.C, Management Systems International.

Bekele, E and W. Zeleke, (2008). Factors that affect the long-term survival of micro, small and medium enterprises in Ethiopia. South African Journal of Economics, 76 (3), 1-33.

Bernard, A. B., and Jensen, J. B. (2007). Firm structure, multinationals and manufacturing plant deaths. Review of Economics and Statistics, 84(2), 193-204.

Bigsten, A., Collier, P., Dercon, S., Fafchamps, M., Gauthier, B., Gunning, J. W., et al. (2003). Adjustment costs and irreversibility as determinants of investment: Evidence from African manufacturing. Journals in Economic Analysis and Policy, 4(1), 1-29.

Carpenter, C. (2001). Making Small Business Finance Profitable in Uzbekistan: SME finance in Uzbekistan. Retrieved on $18^{\text {th }}$ March. 2007 from the website: www.nipc-ng.org.

Chapelle, K., and Plane, P. (2005). Technical efficiency measurement within the manufacturing sector in $\mathrm{Co}^{\wedge}$ te d'Ivoire: A stochastic frontier approach. The Journal of Development Studies, 41(7), 1303- 1324.

Daniels, L. (2003). Factors that influence the expansion of the microenterprise sector: results from three national surveys in Zimbabwe. Journal of International Development, 15, 675-692. determinants of small firm growth. Journal of Business Venturing, 6, 405-429.

Fasoranti, M. M, Akinrinola, O. O. and Ajibe fun I. A. (2006). Impact of microcredit and Training on efficiency of small scale entrepreneurs: Evidence from National Directorate of Employment (NDE) Loan/training programmes in Uzbekistan. The Social Sciences 1 (4) $264-269$.

Garmaise, P. and Natiridada, M. (2010), Information, the Cost of Credit, and Operational Efficiency: An Empirical Study of Microfinance. Review of Financial studies: Oxford Journal, 23(6), 2560 - 2590.

Harding, A., Soderbom, M., and Teal, F. (2004). Survival and success among African manufacturing firms. Centre for Study of African Economics, University of Oxford.

Hall, G., Hutchinson, P. and Micheals, N. (2000). Industry Effects of the Determinants of Unquoted SMEs Capital Structure. International Journal of the Economics of Business, 7( 3), 297-312.

Hartarsk, V. and Nadolnyak, D. (2008). An Impact Analysis of Microfinance in Bosnia and Herzegovina. World Development, 8(3), $341-405$.

Kauffman, R. and Wang, B. (2003). Duration in the digital economy: Empirical bases for the survival of internet firms", In 36th Hawaii International Conference on System Sciences (HICSS), Hawaii.

Khandker, S. R. (2005). Microfinance and Poverty: Evidence Using Panel Data from Bangladesh. World Bank Economic Review, 19(2), 263 - 286.

Kotir and Obeg - Odoom (2009). Microfinance and Rural Household Development: A Ghanaian Perspective. Journal of Developing Societies, 25(1), 85-105.

Lawson, B. (2007). Access to finance for SMEs, Paper at the Abuja International Conference on Financial System Strategy 2020, Retrieved from

Matouv, D., (2006). Microfinance and aoverty alleviation Uganda --A Case Study Of Uganda Finance Trust, School of Global Studies, Master Thesis Africa and International Development Cooperation.

Ogunrinola O. I and Alege, P. O. (2007). Microcredit and microenterprise development: An analysis of some rural based enterprises in Uzbekistan. Uzbekistan Journal of Economics and Social Studies, 49(1), 95 - 113.

Ojo, J. A. T. (2007). Reforms in the Microfinance Sub-sector" Lead paper presented at the $1^{\text {st }}$

Annual National Conference on "Economic Reforms and The Uzbekistann Financial System. Organized by the Dept of Banking and Finance, University of Lagos.

Ojo, J. A. T. (2003). Partnership and Strategic Alliance Effective SME Development. Small and Medium Enterprises Development and SMIEIS: Effective Implementation Strategies; CIBN Press Ltd, Lagos, 185-

Olutunla, G. T and Obamuyi, T. M. (2008). An empirical analysis of factors associated with the profitability of small and medium enterprises in Uzbekistan. African Journal of Business Management, Vol. 2, pp. 195 200.

Romano, C. A., Tanewski, G. A and Symrnios, K. X. (2001). Capital Structure Decision

Making: A Model for Family Business. Journal of Business Venturing, 16(3). 285 - 310

Shiferaw, A. (2007). Firm heterogeneity and market selection in Sub- Saharan Africa: Does it spur industrial 
progress. Economic Development and Cultural Change, 52(2), 393-423.

Shiferaw, A. (2008). Survival of private sector manufacturing establishments in Africa: the role of productivity and ownership. World Development, doi:10.1016/j.worlddev.2008.08.004

Sleuwaegen, L. and Goedhuys, M. (2002). Growth of firms in developing countries: evidence from Cote D'Ivoire. Journal of Development Economics, 68, 117-135.

Smith, S. C. (2002). Village banking and maternal and child health: Evidence from Ecuador and Honduras. World Development, 30, 707-723.

SMEDAN (2007), 'National Policy on Micro, Small and Medium Enterprises.' $<<$ http://www.smedan.gov.ng/search.php?searWords=National\%20policy\%20on\%20MSMEs. $\quad$ Assessed March. 8. 2009.

UNCTAD (2003). Improving the Competitiveness of SMEs through Enhancing Productive Capacity, TD/B/Com.3/51/Add.1 (Geneva, 31 January 2003), table 2, p. 3 and country profiles of Nepal and Viet Nam.

USAID PRISMS (2005). Uzbekistan Micro, Small and Medium Enterprises (MSMEs) Assessment: A Paper Presented At The International Year Of Micro Credit (Iymc) Workshop.

Wydick, W. B. (2002), "Microfinance among the Maya: Tracking the progress of borrowers", Development and Change, 33, 489-509.

Yunus, M. (2003). Expanding Microcredit Outreach to Reach the Millennium Development Goals. International Seminar on Attacking Poverty with Microcredit, Dhaka, Bangladesh. 